\title{
Pengaruh Suhu dan Lama Penyimpanan terhadap Stabilitas Minyak Ikan dan Mikrokapsul Minyak Ikan
}

\section{Effect of Temperature and Storage Time of Fish Oil and Fish Oil Microcapsules Stabilities}

\author{
Montesqrit dan Ovianti. R \\ Fakultas Peternakan Universitas Andalas \\ Kampus Unand Limau Manis Padang, 25163 \\ e-mail: montesqrit@yahoo.com \\ (Diterima: 27 Desember 2012; Disetujui 6 Februari 2013)
}

\begin{abstract}
Fish oil microcapsules could be stored long longer than fish oil. Storage of the fish oil microcapsules to be more stable and effective to note factors such as temperature and storage time. The purpose of this study was to determine the effect of temperature and storage time on the stability of fish oil (MI) and microencapsulated fish oil (MMI). The research method used was a completely randomized design method factorial $2 \times 3$ and 3 replications for each MI and MMI. Factor A (storage temperature: refrigerator temperature and room temperature) and factor $B$ (storage time: 15, 30 and 45 days). The variables measured were peroxide, TBA numbers and the total number of oxidation. The results of this study found that the more stable MMI stored in the refrigerator compared to room temperature and the MMI is more stable compared with MI. Temperature and storage time is best for the oxidative stability of microencapsulated fish oil and fish oil are refrigerator temperature and storage time of 45 days.
\end{abstract}

Key words: stability, fish oil, microcapsule fish oil, temperature

\section{PENDAHULUAN}

Keberadaaan minyak ikan di Indonesia cukup banyak karena Indonesia merupakan negara kepulauan yang mempunyai banyak lautan luas. Salah satu minyak ikan yang banyak ditemukan adalah minyak ikan lemuru yang berasal dari tubuh ikan lemuru. Ikan lemuru tersebut banyak hidup di perairan laut dalam seperti perairan laut di selat Bali. Minyak ikan lemuru yang terdapat di sekitar Selat Bali merupakan hasil samping dari proses pengalengan maupun penepungan ikan lemuru. Kelebihan dari minyak ikan lemuru adalah karena mengandung sumber asam lemak $\omega-3$ berupa kandungan EPA dan DHA yang cukup tinggi. Minyak ikan lemuru sendiri mengandung DHA lebih tinggi dibandingkan dengan minyak ikan tuna. Ikan tuna juga banyak dijumpai di perairan laut dalam Indonesia.
Proses penepungan dan pengalengan ikan lemuru menghasilkan rendeman berupa minyak ikan masing-masing sebesar 5\% (b/b) dan $10 \%(b / b)$. Potensi tersebut belum banyak termanfaatkan dalam ransum ternak. Minyak ikan dapat digunakan untuk meningkatkan asam lemak $\omega-3$ pada produk ternak seperti pada telur,daging maupun susu. Penambahan minyak ikan dalam ransum ayam petelur dapat meningkatkan kandungan asam lemak $\omega-3$ terutama EPA (Eicosapentanoic Acid) dan DHA (Dacosahexanoic Acid) pada kuning telur (Sudibya, 1998; Montesqrit dan Adrizal 2009).

Penggunaan minyak ikan dalam ransum ternak kurang efektif dan efisien. Hal ini disebabkan karena sulitnya dalam penyimpanan dan penanganan sebelum digunakan sebagai bahan pakan. Minyak ikan banyak mengandung asam lemak tidak jenuh rangkap ganda yang menyebabkan mudah teroksidasi sehingga menyulitkan dalam hal penyimpanan. Mi- 
nyak ikan yang sudah teroksidasi mempengaruhi kualitas dan kandungan asam lemak omega-3 yang dimilikinya.

Upaya untuk mengatasinya selama ini adalah dengan penambahan bahan kimia yang mencegah terjadinya oksidasi tersebut, hal ini tentu menambah biaya dan juga terjadinya residu bahan kimia dalam ternak yang mengkonsumsi, padahal kita menginginkan ternak yang akan dikonsumsi adalah ternak organik yaitu ternak yang tidak mengandung bahan kimia dari pakan yang dikonsumsi. Upaya lain untuk menjaga agar minyak ikan tidak terjadi oksidasi adalah dengan cara proses mikroenkapsulasi pada minyak ikan tersebut.

Proses mikroenkapsulasi adalah proses memerangkap minyak ikan dengan menggunakan bahan penyalut dan selanjutnya dilakukan proses pengeringan dengan pengering semprot atau pengering drum. Keuntungan dari mikroenkapsulasi ini adalah di samping wujudnya berubah menjadi tepung atau bubuk dan yang paling penting adalah dapat dilindunginya minyak ikan tersebut dari proses oksidasi sehingga minyak ikan dapat disimpan lebih lama dan lebih efisien untuk dicampurkan ke dalam ransum (Andersen, 1995; Keogh et al., 2001; Subramanian dan Stagnitti, 2004). Minyak ikan yang diperoleh dengan cara mikroenkapsulasi dapat menekan atau memperlambat terjadinya oksidasi (Kolanowski et al., 2004).

Produk dari proses mikroenkapsulasi minyak ikan ini biasa juga disebut mikrokapsul minyak ikan. Mikrokapsul ini sudah banyak dimanfaatkan pada bidang pangan akan tetapi penggunaannya dalam campuran pakan masih terbatas, hal ini disebabkan karena bahan penyalut yang digunakan adalah produk pangan yang harganya cukup tinggi seperti gum arab, gelatin, lesitin dan isolat protein kedele. Hasil penelitian Montesqrit (2007) serta Montesqrit dan Adrizal (2009) telah mengganti penggunaan bahan penyalut tersebut dengan bahan pakan sehingga produk mikrokapsul yang dihasilkan dapat dimanfaatkan untuk dicampurkan ke dalam ransum. Mikrokapsul yang diperoleh tersebut perlu dilihat stabilitasnya.
Stabilitas mikrokapsul ditandai dengan kemampuan bahan penyalut untuk melindungi bahan inti dari pengaruh lingkungan yang tidak diinginkan seperti cahaya, udara (oksigen), suhu dan lain-lain. Untuk menguji tingkat kestabilan mikrokapsul dan minyak ikan dapat dilakukan dengan pengujian stabilitas oksidatif guna melihat laju oksidasi dan lama daya simpan dari mikrokapsul dan minyak ikan. Minyak ikan yang disalut oleh bahan penyalut melalui proses mikroenkapsulasi lebih stabil dibandingkan dengan minyak ikan tanpa diproteksi. Montesqrit (2007) telah mendapatkan bahwa mikrokapsul minyak ikan lebih stabil dibandingkan dengan minyak ikan tanpa diproteksi, hal ini dapat dilihat lebih rendahnya total bilangan oksidasi pada mikrokapsul minyak ikan dibandingkan dengan minyak ikan tanpa proteksi.

Stabilitas mikrokapsul dan minyak ikan dapat dipengaruhi oleh suhu dan lama penyimpanan. Semakin tinggi suhu dalam penyimpanan maka semakin pendek bahan tersebut dapat disimpan untuk jangka waktu yang lama. Suhu penyimpanan dan lama penyimpanan saling berkaitan satu sama lain, jika bahan pakan disimpan pada suhu tinggi maka waktu penyimpanan tidak akan bertahan lama, karena bahan pakan mengalami kerusakan yang dapat menurunkan kualitas bahan pakan tersebut. Kondisi suhu dan lama penyimpanan yang efektif untuk penyimpanan minyak ikan dan mikrokapsul minyak ikan belum ada dilaporkan, berdasarkan hal tersebut maka perlu dilakukan penelitian untuk mengetahui pengaruh suhu yang efektif dan lama penyimpanan yang baik terhadap kestabilan mikrokapsul minyak ikan.

\section{METODE}

Bahan-bahan yang digunakan dalam penelitian adalah minyak ikan lemuru dan mikrokapsul minyak ikan. Minyak ikan lemuru diperoleh dari limbah hasil penepungan ikan di Banyuwangi Jawa Timur, sedangkan mikrokapsul minyak ikan dibuat menggunakan bahan penyalut berupa tepung daging dan bungkil kelapa selanjutnya dilakukan pengeri- 
ngan dengan menggunakan pengering semprot (Montesqrit dan Adrizal, 2009). Selanjutnya digunakan juga bahan- bahan kimia untuk uji stabilitas oksidatif minyak ikan dan mikrokapsul minyak ikan.

Metode yang digunakan adalah metode ekperimen dengan menggunakan Rancangan Acak Lengkap pola faktorial 2 x 3 dan 3 ulangan untuk masing-masing minyak ikan dan mikrokapsul minyak ikan. Faktor A (suhu penyimpanan : suhu refrigerator dan suhu ruang) dan faktor B (lama penyimpanan : 15, 30 dan 45 hari). Peubah yang diamati: Bilangan Peroksida dengan Metoda Titrasi (Soedarmadji, 1984), Bilangan TBA dengan Metode AOCS cd 19-90 (1990) dan Bilangan Total Oksidasi (Budjianto, 2001).

Penelitian ini diawali dengan penimbangan sampel sebanyak $15 \mathrm{~g}$ dan dimasukan ke dalam vial yang ditutup dengan aluminium foil. Sampel disimpan dalam suhu refrigerator $\left(8^{0} \mathrm{C}\right)$ dan suhu ruang $\left(27^{\circ} \mathrm{C}\right)$ selama perlakuan (15, 30 dan 45 hari). Kemudian dilakukan analisa terhadap peubah-peubah yang diuji.

\section{HASIL DAN PEMBAHASAN}

\section{Pengaruh Suhu dan Lama Penyimpanan Minyak Ikan dan Mikrokapsul Minyak Ikan terhadap Bilangan Peroksida}

Pada Gambar 1A terlihat bilangan peroksida pada minyak ikan berkisar antara 7.39 $\mathrm{meq} / \mathrm{kg}-20.84 \mathrm{meq} / \mathrm{kg}$. Terjadi interaksi antara suhu dan lama penyimpanan dimana semakin tinggi suhu dan lama penyimpanan maka semakin tinggi bilangan peroksida. Penyimpanan dalam suhu ruang $\left(27^{\circ} \mathrm{C}\right)$ memperoleh bilangan peroksida lebih tinggi jika dibandingkan dengan penyimpanan dalam suhu refrigerator $\left(8^{0} \mathrm{C}\right)$, begitu juga dengan lama penyimpanan. Minyak ikan yang disimpan dalam waktu lama mengakibatkan bilangan peroksidanya lebih tinggi dibandingkan dengan waktu penyimpanan yang lebih pendek.

Terjadinya peningkatan bilangan peroksida minyak ikan pada suhu ruang dan lama penyimpanan 45 hari disebabkan terbentuknya reaksi kimia antara minyak dengan oksigen sehingga akan membentuk persenyawaan peroksida yang dapat membantu terjadinya proses oksidasi sejumlah kecil asam lemak tidak jenuh, selain itu disebabkan oksigen bebas di bawah pengaruh sinar ultraviolet atau katalis logam. Ketaren (1986) menjelaskan bahwa dengan bertambahnya ikatan rangkap pada rantai molekul akan mengakibatkan asam lemak bersifat semakin reaktif terhadap oksigen.

Terjadinya oksidasi pada minyak ikan akan menghasilkan produk primer dalam bentuk peroksida. Peroksida bersifat sangat labil dan mudah mengalami dekomposisi oleh proses isomerasi atau polimerasi dan akhirnya menghasilkan senyawa dengan berat molekul yang lebih rendah. Senyawa tersebut seperti aldehid dan keton, senyawa ini juga bersifat labil sehingga terdekomposisi menghasilkan turunan-turunan berikutnya dan akhirnya membentuk polimer-polimer. Satu molekul oksigen yang bereaksi dengan ikatan tidak jenuh akan menghasilkan oksida lemak dan secara simultan membebaskan atom oksigen aktif.

Bilangan peroksida dapat mempengaruhi daya simpan suatu produk, dimana bilangan peroksida yang tinggi maka produk tersebut tidak tahan disimpan lama sebaliknya jika bilangan peroksida rendah maka daya simpan akan lebih lama (Budijanto et al., 2001). Bilangan peroksida dapat digunakan untuk menentukan tingkat kerusakan lemak pada minyak atau pada bahan pangan berlemak. Semakin tinggi bilangan peroksida maka semakin tinggi tingkat kerusakan lemak tersebut.

Pada Gambar 1 (B) terlihat tidak ada interaksi antara suhu dan lama penyimpanan, akan tetapi perbedaan suhu sangat nyata $(\mathrm{P}<0.01)$ mempengaruhi bilangan peroksida. Mikrokapsul yang disimpan pada suhu refrigerator (suhu $8^{0} \mathrm{C}$ ). mendapatkan bilangan peroksida lebih rendah dibandingkan dengan disimpan pada suhu ruang, sedangkan lama penyimpanan tidak mempengaruhi bilangan peroksida 


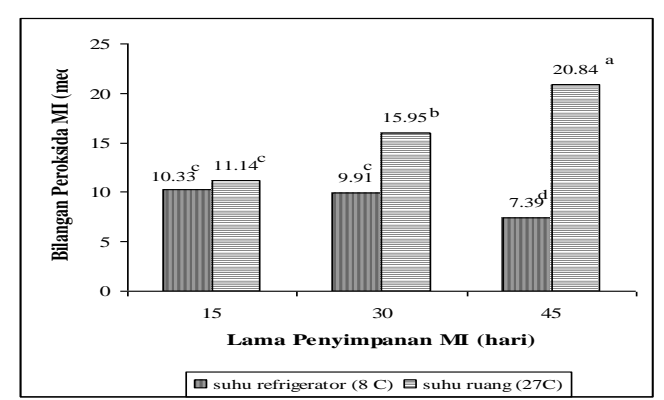

(A)

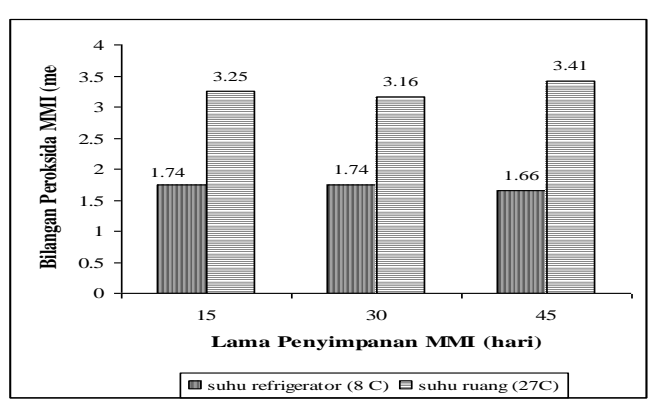

(B)

Gambar 1. Pengaruh suhu dan lama penyimpanan minyak ikan (A) dan mikrokapsul minyak ikan (B) terhadap bilangan peroksida

baik pada suhu ruang maupun suhu refrigerator.

Tingginya nilai bilangan peroksida mikrokapsul pada suhu $27^{\circ} \mathrm{C}$ disebabkan adanya kontak sejumlah oksigen dengan minyak /lemak sehingga mikrokapsul teroksidasi. Pada suhu $27^{\circ} \mathrm{C}$ oksigen yang menyerang minyak lebih banyak dibanding oksigen yang diperlukan untuk memecah hidroperoksida menjadi senyawa sekunder sehingga akan lebih banyak dihasilkan senyawa peroksida yang mempercepat terjadinya proses oksidasi, dimana senyawa peroksida mampu mengoksidasi molekul asam lemak yang masih utuh dengan cara melepaskan 2 atom hydrogen sehingga membentuk ikatan rangkap baru dan selanjutnya direduksi sampai membentuk oksida.

Nilai bilangan peroksida pada MMI selalu lebih rendah dibandingkan dengan MI, dengan selisih sebesar 5 sampai $8 \mathrm{meq} / \mathrm{kg}$ penyimpanan pada suhu refrigerator dan sebesar 8 sampai $17 \mathrm{meq} / \mathrm{kg}$ pada suhu ruang. Hal ini menunjukkan bahwa mikrokapsul memberikan perlindungan yang efektif terhadap kerusakan oksidatif minyak serta membuktikan bahwa dengan proses mikroenkapsulasi dapat mengurangi tingkat kerusakan pada minyak dengan cara menekan laju oksidasi sehingga mikrokapsul tetap stabil. Menurut Kolanowski et al., (2004) proses mikroenkapsulasi pada minyak ikan dapat menekan /memperlambat terjadinya oksidasi. Jika penyimpanan dilanjutkan perubahan bilangan peroksida pada mikrokapsul tidak akan melebihi 8,2 meq/kg dalam waktu yang cepat.
Berdasarkan hal tersebut daya simpan mikrokapsul ini dapat bertahan lama karena menurut Andersen (1995) mikrokapsul minyak ikan dengan bilangan peroksida tidak lebih dari 8,2 $\mathrm{meq} / \mathrm{kg}$ dapat disimpan sampai 2 tahun.

\section{Pengaruh Suhu dan Lama Penyimpanan Minyak Ikan dan Mikrokapsul Minyak Ikan terhadap Bilangan TBA}

Pada Gambar 2 terlihat bilangan TBA pada minyak ikan berkisar antara 23.63 $47.30 \mathrm{nmol} / \mathrm{gr}$ (gambar 2A) dan sebesar 17.70 - $47.30 \mathrm{nmol} / \mathrm{gr}$ pada MMI (Gambar 2B). Berdasarkan analisis ragam menunjukkan tidak terjadi interaksi antara suhu dan lama penyimpanan, demikian juga suhu dan lama penyimpanan tidak nyata $(\mathrm{P}>0.01)$ mempengaruhi nilai bilangan TBA baik pada MI maupun MMI.

Pengukuran bilangan TBA adalah salah satu metode yang digunakan untuk menentukan produk sekunder hasil oksidasi minyak. Uji TBA merupakan metode sederhana dan cepat untuk menentukkan tingkat degradasi lemak dari aldehid yang tidak dapat dimetabolisme seperti malonaldehid. Penentuan bilangan TBA ini berdasarkan pengukuran konsentrasi malonaldehid yang terbentuk dalam sampel minyak selama proses oksidasi (Budjianto et al., 2001). Pada pengukuran bilangan TBA lebih spesifik untuk mengukur jumlah aldehid yang merupakan hasil dekomposisi degradasi sekunder, aldehid merupakan bagian dari karbohidrat yang tidak 


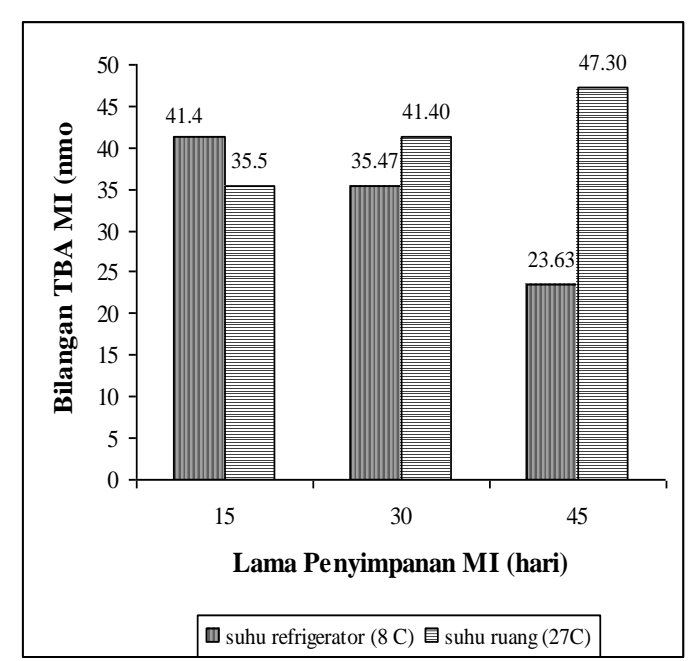

(A)

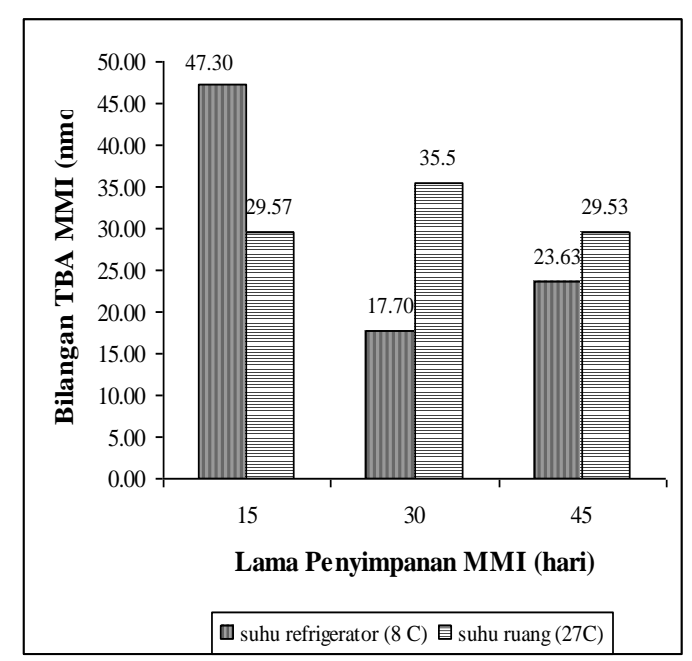

(B)

Gambar 2. Pengaruh suhu dan lama penyimpanan minyak ikan (A) dan mikrokapsul minyak ikan (B) terhadap nilai bilangan TBA

terdapat pada minyak sehingga pada pengukuran TBA minyak ikan angka bilangan TBA yang didapat rendah. Hasil penelitian Montesqrit (2007), selama penyimpanan minyak ikan sampai minggu ke-4 didapatkan angka bilangan TBA $2,19 \mu \mathrm{mol} / \mathrm{gr}$. Tidak adanya pengaruh perlakuan suhu dan lama penyimpanan terhadap bilangan TBA pada MI maupun MMI disebabkan karena pada pengujian stabilitas oksidatif lebih spesifik melihat tingkat oksidasi dari minyak atau lemak tersebut dan selama penyimpanan pemecahan asam lemak dalam mikrokapsul tidak terlalu tinggi menghasilkan senyawa malonaldehid atau keton yang merupakan senyawa yang toksik. Walaupun Bilangan TBA tidak nyata mempengaruhi MI dan MMI akan tetapi bilangan TBA tersebut sangat diperlukan untuk mengukur bilangan total oksidasi minyak/lemak.

\section{Pengaruh Suhu dan Lama Penyimpanan Minyak Ikan dan Mikrokapsul Minyak Ikan terhadap Bilangan Total Oksidasi}

Pada Gambar 3 terlihat bilangan total oksidasi pada minyak ikan berkisar antara 14.80 - 41.72 (gambar 3A) dan sebesar 3.35 6.85 pada MMI (Gambar 3B). Berdasarkan analisis ragam menunjukkan terjadi interaksi antara suhu dan lama penyimpanan pada MI sedangkan pada MMI tidak terjadi interaksi antara suhu dan lama penyimpanan akan tetapi perbedaan suhu sangat nyata $(\mathrm{P}>0.01)$ mempengaruhi bilangan total oksidasi pada MMI.

Bilangan total oksidasi yang terendah pada MI diperoleh pada perlakuan suhu $8^{0} \mathrm{C}$ dan lama penyimpanan 45 hari yaitu sebesar 14,80 dan angka tersebut lebih rendah dibandingkan dengan MI kontrol $(22,18)$ dan perlakuan lainnya. Rendahnya bilangan total oksidasi minyak ikan pada suhu $8^{\circ} \mathrm{C}$ disebabkan karena tidak adanya cahaya yang dapat kontak langsung dengan minyak ikan, selain itu juga pada suhu rendah dapat menghambat terjadinya proses oksidasi minyak. Ketaren (1986) menjelaskan kecepatan oksidasi minyak/lemak yang dibiarkan di udara akan bertambah dengan kenaikan suhu dan akan berkurang dengan penurunan suhu. Montesqrit (2007) mendapatkan selama penyimpanan MI sampai minggu ke 4 diperoleh bilangan total oksidasi sebesar 24,76 .

Rendahnya bilangan total oksidasi MMI pada suhu ruang disebabkan karena bilangan peroksida MMI pada suhu ruang juga lebih rendah sementara kandungan produk skunder hasil oksidasi yang diukur dengan bilangan TBA belum menunjukkan peningkatan. Bilangan total oksidasi dipengaruhi oleh bilangan 


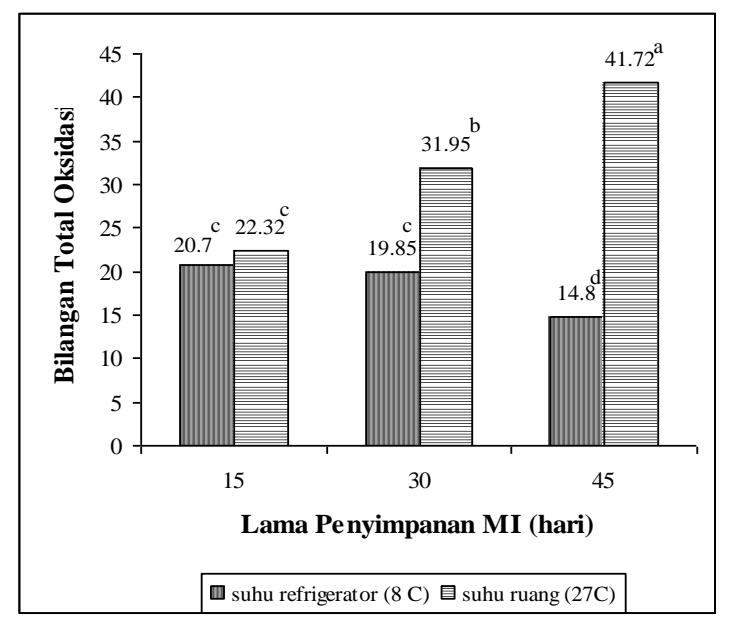

(A)

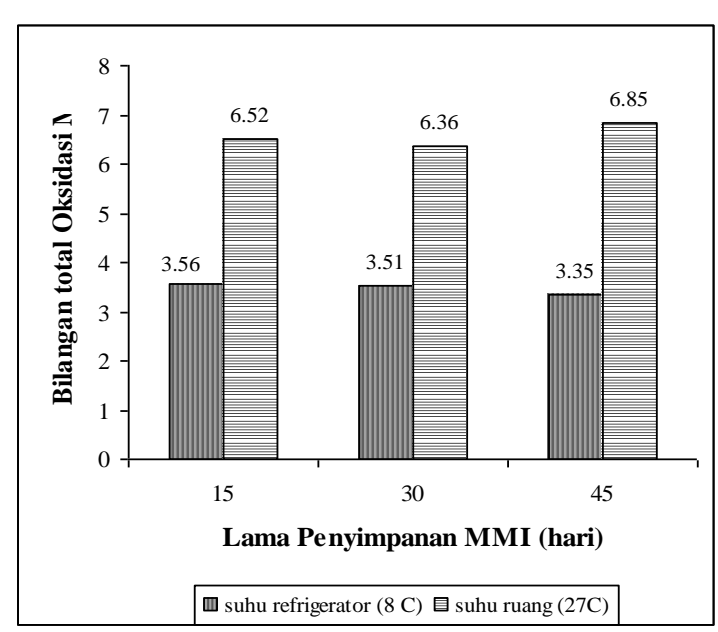

(B)

Gambar 3. Pengaruh suhu dan lama penyimpanan minyak ikan (A) dan mikrokapsul minyak ikan (B) terhadap bilangan total oksidasi

peroksida dan bilangan TBA, nilainya diperoleh dengan menjumlahkan dua kali bilangan peroksida dengan bilangan TBA. Selain itu juga karena terlindunginya minyak ikan pada proses mikroenakpsulasi dari oksidasi karena adanya imbangan karbohidrat dan protein dalam bahan penyalut sehingga mikrokapsul yang dihasilkan mengandung tinggi kadar minyak terkapsul (Montesqrit, 2007). Menurut Ono dan Aoyama (1979) imbangan karbohidrat dan protein dalam bahan penyalut dapat memberikan perlindungan yang baik terhadap mikrokapsul sehingga mikrokapsul tetap stabil dan daya simpan dapat bertahan lama.

Tingginya bilangan total oksidasi mikrokapsul pada suhu $27^{\circ} \mathrm{C}$ dapat terjadi karena adanya proses oksidasi. Bahan pangan yang berlemak akan lebih mudah teroksidasi jika ada oksigen dan cahaya yang merupakan akselerator terjadinya proses oksidasi.

Bilangan total oksidasi mikrokapsul minyak ikan selalu lebih rendah bila dibandingkan dengan minyak ikan, hal ini disebabkan adanya bahan penyalut yang melindungi minyak ikan. Rosenberg et al. (1990) menjelaskan bahwa mikroenkapsulasi merupakan teknik perlindungan atau pengemasan droplet cairan atau partikel padat yang didesain untuk melindungi bahan yang dienkapsulasi dari faktor-faktor yang dapat mengakibatkan kerusakan.
Angka bilangan total oksidasi pada mikrokapsul selalu lebih rendah jika dibandingkan dengan minyak ikan dari penyimpanan 15 sampai 45 hari. Hal ini menunjukkan bahwa mikrokapsul memberikan perlindungan yang efektif terhadap kerusakan oksidatif minyak serta membuktikan bahwa dengan proses mikroenkapsulasi dapat mengurangi tingkat kerusakan pada minyak dengan cara menekan laju oksidasi sehingga mikrokapsul tetap stabil. Kolanowski et al. (2004) menyatakan proses mikroenkapsulasi pada minyak ikan dapat menekan terjadinya oksidasi.

\section{KESIMPULAN}

Suhu dan lama penyimpanan yang terbaik untuk kestabilan oksidatif minyak ikan dan mikrokapsul minyak ikan adalah suhu refrigerator $8^{\circ} \mathrm{C}$ dan lama penyimpanan 45 hari. Mikrokapsul minyak ikan jauh lebih stabil dari pada minyak ikan pada berbagai suhu dan lama penyimpanan dimana terlihat pada bilangan peroksida dan bilangan total oksidasinya yang rendah.

\section{DAFTAR PUSTAKA}

[AOAC] Association of Official Analytical Chemist. 1984. Official Standard of 
Analysis. Ed ke-14. Arlington Virginia: AOAC.

Andersen S. 1995. Microencapsulated omega3 fatty acids from marine sources. Lipid Technology 7:81-85

Budijanto, S., N, Andarwulan dan D, Herawati. 2001. Teori dan Praktek Kimia dan Teknologi Lipida. Jurusan Teknologi Pangan dan Gizi Fakultas Teknologi Pertanian Institut Pertanian Bogor, Bogor.

Keogh, MK., BT. O'Kennedy., J. Kelly., MA. Auty., PM. Kelly., A. Fureby and AM. Haar. 2001. Stability to oxidation of spray-dried fish oil powder microencapsulated using milk ingredients. Journal Food Science. 66:217224.

Ketaren, S. 1986. Minyak dan Lemak Pangan. Universitas Indonesia, Jakarta.

Kolanowski, W., G, Laufenberg and B, Kunz. 2004. Fish oil stabilisation by microencapsulation with modified cellulose. International Journal Food Science Nutrition. 55:333-343.

Montesqrit. 2007. Penggunaan bahan pakan sebagai bahan penyalut dalam mikroenkapsulasi minyak ikan lemuru dan pemanfaatannya dalam ransum ayam petelur. Disertasi. Institut Pertanian Bogor.
Montesqrit dan Adrizal. 2009. Optimasi produksi mikrokapsul minyak ikan sebagai feed aditif untuk menghasilkan produk unggas kaya asam lemak omega-3 dan rendah kolesterol. Laporan Akhir Hibah Bersaing tahun 2008. Universitas Andalas

Ono, F and Y. Aoyama. 1979. Encapsulation and stabilization of oily substances by protein and carbohydrate. Journal Japan Soc Food Technology. 26:1317.

Rosenberg, M., I.J. Kopelman and Y. Talmon. 1990. Factors affecting retention in spray drying microencapsulation of volatile materials. J. Agric. Food chemistry. 38:1288-1294.

Soedarmadji. 1984. Prosedur Analisa untuk Bahan Makanan dan Pertanian Edisi, Ketiga. Liberty, Yogyakarta.

Subramanian, S and G. Stagnitti. 2004. Stabilization of omega-3 fatty acid with encasulation technologies. http://ift.confex.com/ift/2004/techprog ra/session-2727.htm. Diakses tanggal 15 Januari 2010.

Sudibya. 1998. Manipulasi kadar kolesterol dan asam lemak omega-3 telur ayam melalui penggunaan kepala udang dan minyak ikan lemuru. Disertasi. Program Pascasarjana Institut Pertanian Bogor, Bogor. 